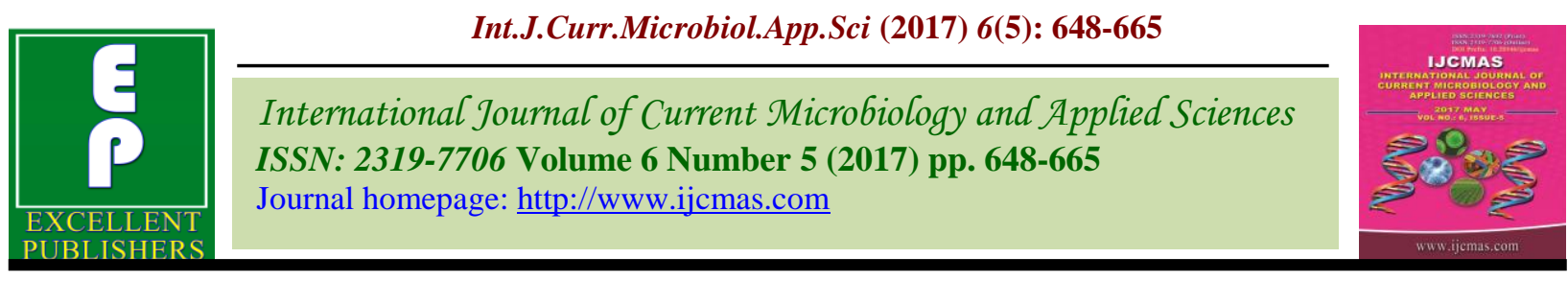

Review Article

https://doi.org/10.20546/ijcmas.2017.605.075

\title{
Bio-efficacy of Organic Formulations on Crop Production-A Review
}

\author{
Sudhanshu Verma*, Abhishek Singh, Swati Swayamprabha Pradhan, \\ R.K. Singh and J.P. Singh
}

\author{
Department of Agronomy, Institute of Agricultural Sciences, \\ Banaras Hindu University, Varanasi, U.P. India \\ *Corresponding author
}

\begin{tabular}{|c|c|}
\hline & A B S T R A C T \\
\hline Keywords & \multirow{4}{*}{$\begin{array}{l}\text { Indiscriminate use of the fertilizer, pesticide has harmful effects on soil health, } \\
\text { human health, ground water health and environment. This will caused more } \\
\text { dangerous effect for future possibility. Present status of all food grain production } \\
\text { is in enough quantity for population of our country so we need to quality of food } \\
\text { production, quality of soil, quality of ground water and quality or healthy } \\
\text { environment for better livelihood. These qualities are obtained by the replacing } \\
\text { inorganic input through organic input which is more vital for present prospect and } \\
\text { future outlook. This review paper attempts to bring together different use of } \\
\text { organic formulation in crop production and protection. It has been argued that } \\
\text { organic formulation in crop production is productive and sustainable, but there is a } \\
\text { need for strong support to it in the form of manifestation of subsidies, agricultural } \\
\text { extension services and research. }\end{array}$} \\
\hline $\begin{array}{l}\text { Organic } \\
\text { formulation, } \\
\text { Inorganic input, } \\
\text { Quality. }\end{array}$ & \\
\hline Article Info & \\
\hline $\begin{array}{l}\text { Accepted: } \\
\text { 04 April } 2017 \\
\text { Available Online: } \\
10 \text { May } 2017\end{array}$ & \\
\hline
\end{tabular}

\section{Introduction}

The exploitative agriculture for a long time in our country has brought down the fertility status of the soil to a level that even provision of high rate of fertilizers is unable to sustain the productivity of soil. So as to sustain the productivity of soil and promote the health of the soil, combine use of organic and chemical fertilizers is imperative.

Chemical fertilizers alone do not provide all the nutrients in balanced quantities needed by the plants; on the other hand it depletes soil organic matter content, adversely affect biological and physical properties of soil. All the considerations in general have led to prompted interest towards the utilization of organic manures. The utilisation of organic manure not only best serves with manage crop yields but also play a key role towards exhibiting both direct as well as indirect influence on the nutrient accessibility in soil by improving the physical, chemical and biological properties of soil and likewise enhances the utilization effectiveness of applied fertilizers.

The escalating price of fertilizers in recent years, limit their use in crop production. Therefore, the nutrient requisition through chemical fertilizers, if supplemented with low expense natural sources will not only economize the nutrient use but also improve 
the soil health and factor productivity on sustainable basis.

Crop + dairy is the predominant cultivating framework in the country practiced by over $70 \%$ farm households. The abundant quantity of cattle excreta consisting of dung and urine is available at rural family. In spite of and only cows dung is utilized likewise manure yet significant amount of urine goes waste. However, cattle urine has a good manurial value and can be utilized as a bio fertilizer (Khanal et al., 2011). Cattle urine is a good source of nitrogen, phosphate, potassium, calcium, magnesium, chlorite and sulphate. Application of cow urine has also been reported to correct the micronutrient deficiency, besides improving the soil texture and working as a plant hormone.

Vermiwash obtained from dissolution of organic matter by earthworm is additionally found as a good liquid manure and influence altogether on the development and and productivity of crop as foliar spray (Subasashri, 2003). It is coelomic fluid extraction contains several enzyme, plant growth stimulating hormones like cytokinins, gibberlines and vitamins along with micro and macro nutrients as nitrogen in the form of mucus, nitrogenous excretory substance, enzyme are present in vermiwash (Tripathi and Bhardwaj, 2004). It also increases the disease resistant power of crop, (Yadav et al., 2005).

Neem seed extract performs the dual function of both fertilizer and pesticide of organic origin. It also acts as a soil enricher, reduces the growth of soil pest and bacteria.

Moreover it provides macro-nutrients essential for all plant growth, helps to increase the yield of plants in the long run, bio-degradable and Eco-friendly and excellent soil conditioner (Lokanadhan et al., 2012).
In some conventional practices of some areas near fish production sites waste product of fishes are also used as nutrient supplement. Recent studies also revealed potential of such sources in INM. Fermented fish waste is found to enrich the soil nutrients required for plant growth and favourably influence the conducting functions of xylem and phloem vessels. Thus fish waste could also be used as a valuable organic liquid fertilizer for better yield from crops at lesser cost and also without the harmful effects of chemical fertilizers (Balraj et al., 2014). Also the fish effluents can supplement for organic fertilizers without affecting fish production. The recirculatory aquaponics system proved, is not only a successful method for food crops production, but also a beneficial system to reuse aquaculture wastewater and safeguard the water resources (Salam et al., 2014).

Therefore, it seems that formulations obtained from by product or waste from livestock and fish rearing, vermiwash and some plant products based integrated nutrient management system in crop production has a great potential to supplement and reduce nutrient demand solely supplied through inorganic chemicals. Due to low cost of these inputs crop production could be economized. This will also improve the fertilizer use efficiency as well as the soil health. With these facts in view, a field experiment was conducted to explore the possibility of economizing fertilizer use in pigeonpea by partial replacement of fertilizer through organic formulation as bio-fertilizer.

\section{Cow Urine}

Andreeilee et al., (2015) reported that combination of organic materials (feces + urine + paitan + Mycorrhiza + Azola $2 \mathrm{~kg}$ ) and (feces + urine + paitan + mycorrhiza + azola $3 \mathrm{~kg}$ ) showed significant value to the entire organ growth vegetative plant with the 
highest increase in the broad leaves of the plant by $3 \mathrm{~cm}$ or $19.57 \%$ by treatment effect at 63 DAP when compared to the control treatment of inorganic fertilizer with the addition of the same Azola dosages. Minocheherhomji and Vyas (2014) reported that phyto chemical investigation of cow urine sample and medicinal plant extracts will definitely prove the presence of active phyto constituents like alkaloids, anthraquinones, flavonoids, tannins and saponins; which are the main constituents promoting antimicrobial activity. Singh et al., (2015) reported that the application of cow urine on buckwheat recorded higher plant height $(116.2 \mathrm{~cm})$, stem girth $(0.64 \mathrm{~cm})$, leaves plant-1(13.5), root length $(12.6 \mathrm{~cm})$, seed plant-1(102), and test weight (22.4) as compared to control. Sobhana (2014) reported enhance flower production in bush jasmine using bioregulators and cow's urine. One year old plants grown in pots were sprayed with paclobutrazol, cycocel, GA3 and cow's urine at various concentrations at monthly intervals. Observations on vegetative and floral characters were recorded and concluded that monthly flower yield was improved by the application of cow's urine and bio regulators. Akhter et al., (2006) reported that C. procera extract in combination with cow urine posses high ability to inhibit conidial germination of B. sorokiniana, which might be used for controlling phytopathogens of crop plants. Gupta (2005) reported that neem in combination with cow urine has been also found effective in reducing the mustard aphid population with no adverse effect on coccinellid predators. Geetanjaly and Tiwari (2014) observed that the effects of cow urine, neem leaf extract (5\% and 10\%) against different stages of Spilarctia obliqua. The cent percent mortality of neonate larvae was observed in all neem leaf extracts prepared in water and cow urine whereas in cow urine @ $5 \%$ and $10 \%$ gave larval survival of $26.63 \%$ to $13.34 \%$, with significantly less growth index (0.284) in comparison to untreated control (3.050). Kekuda et al., (2014) reported that the cow urine extracts of selected plants have shown inhibitory activity against mycelial growth of chilli. These formulations can be employed in the field for the control of anthracnose disease in chilli. Devakumar et al., (2014) was conducted an experiment to study the influence of different levels of cow urine, panchagavya and fertility on maize. The grain and stover yield of maize varied significantly under different levels of fertility, panchagavya spray and cow urine levels. Maximum grain yield of $18.6 \mathrm{q} \mathrm{ha}^{-1}$ and $17.6 \mathrm{q} \mathrm{ha}$ were recorded with application of cow urine and panchagavya and minimum was recorded in the plots without application of them. However, no significant difference was observed in stover yield but, higher stover yield of $42.7 \mathrm{q} \mathrm{ha}^{-1}$ and $39.6 \mathrm{q} \mathrm{ha}^{-1}$ were recorded in the plots with application of panchagavya and cow urine. Lithourgidis et al., (2007) observed that soil application of liquid cattle manure (LCM) (excrements plus urine, occasionally containing bedding material) can enhance plant growth and increase crop yield as well as increases in plant macronutrients concentration or uptake. Rakesh et al., (2013) showed that the marked inhibition of rhizome rot pathogens by cow urine extracts of selected plants. The extracts may find a possible use in agriculture as potent agents against pathogens. Pathak and Ram (2013) were concluded that bio enhancers could be a potent source to improve soil fertility, crop productivity and quality. This can also be a potential alternative for fertigation which is becoming common in most of the crops. Gahukar (2013) was reported that the combinations of cow urine and plant parts and neem-based commercial products have shown significant synergistic effect to enhance product toxicity resulting in pest mortality. Patil et al., (2012) observed that application of cow urine on chickpea at the rate of $10 \%$ 
at flowering initiation and 15 days after flowering recorded higher plant height $(35.78 \mathrm{~cm})$ at harvesting, number of branches at harvesting (4.82), leaf area index at 90 DAS (1.30), number of pod plant-1(60.86), and grain yield $\left(2114 \mathrm{~kg} \mathrm{ha}^{-1}\right)$ as compare to control. Deotale et al., (2011) observed the effect of two foliar sprays of different concentrations of NAA (50 ppm) and cow urine $(2 \%, 4 \%, 6 \%)$ at 25 and 40 days after sowing on soybean cultivar JS-335. The cow urine $6 \%$ concentration spray and $50 \mathrm{ppm}$ NAA alone and in combination were found more effective in enhancing the morphophysiological, chemical biochemical, yield and yield contributing parameters when compared with control. Baghele et al., (2014) reported that two sprays of cow urine @ $3 \%$ enhanced growth, flowering and yield parameters of rose. Qibtiyah et al., (2015) reported that the dosage of biourine that comprises of 4 levels: 0, 500, 1000, 1500 and $20001 \mathrm{ha}^{-1}$ showed a significant of effect on diverse-observed parameter of growth, the application of $15001 \mathrm{ha}^{-1}$ and $2000 \mathrm{l} \mathrm{ha}^{-1}$ could increase leaf area, numbers of plantlet per clump and total dry weight of the crops, which are better than other treatments. Mudhita et al., (2016) reported that the legume plant Pueraria javanica showed good growth and production with a relatively high nutrient value of Bali cattle urine, although nutrient values did not significantly differ between treated and untreated plants. The highest production of dry matter per $\mathrm{m}^{2}$ was 937 and $838 \mathrm{~g}$, with and without urine, respectively, which represents an increase of $11.8 \%$. Meanwhile the nitrogen contents of urine-treated plants increased by $24.6 \%$ relative to untreated plants. Ramachandrudu and Thangam (2007) examined the application of cow urine @ $(10,20,50$, $100 \%$ ) on gladiolus, application of $50 \%$ cow urine recorded higher plant height $(59.90 \mathrm{~cm})$,number of leaf $\operatorname{plant}^{-1}(9.40)$, number of florets spike ${ }^{-1}(10.70)$, number of cornels plant ${ }^{-1}$ (75.70) and number of corns plant $^{-1}$ as compare to other treatments. Rates of application of nitrogen $(\mathrm{N})$, potassium $(\mathrm{K})$, and sulphur (S) in urine are very high and these can have a marked effect on growth and element concentration of pasture ( McNaught, 1961). Ledgard, et al., (1982) in New Zealand, evaluated the effects of cow urine and equivalent nitrogen, potassium, and sulphur treatments on pasture yield, botanical composition, herbage chemical composition and $\mathrm{N}$ fixation by clovers during winter and spring. They noticed that urine caused a large increase in ryegrass yield, entirely due to its $\mathrm{N}$ content. The effect on yield lasted 2 to 3 harvests. Urine increased the $\mathrm{N}$ concentration of grass (particularly the nitrate fraction) and increased the potassium concentration of grass and clover. Saunders (1987) examined the effects of cow urine and equivalent nitrogen, potassium, and sulphur treatments on pasture yield, botanical composition, herbage chemical composition, and $\mathrm{N}$ fixation by clovers during winter and spring. Urine caused a large increase in ryegrass Yield, due to entirely its $\mathrm{N}$ component. The effect on yield lasted 2-3 harvests and was followed by a decrease in clover growth. Urine increased the $\mathrm{N}$ concentration of grass (particularly the nitrate fraction) and increased the potassium concentration of grass and clover. $\mathrm{N}$ fixation by clover was markedly decreased by urine, particularly during the winter. Leterme et al., (2003) used cow urine to study the fate of $\mathrm{N}$ applied as urine in spring, summer and autumn on ryegrass receiving two different fertilizer rates (100 and $\left.300 \mathrm{~kg} \mathrm{~N}^{-1} \mathrm{yr}^{-1}\right)$ in France. Ammonia volatilization of labeled urine $\mathrm{N}$ was less than $4 \%$ and immobilized urine $\mathrm{N}$ represented $21-31 \%$ of the applied 15 $\mathrm{N}$. Recovery of labeled $\mathrm{N}$ in plants ranged from 30 to $65 \%$ of $\mathrm{N}$ input as urine, showing a decrease in autumn for the highest fertilizer nitrogen treatment. The plant recovery of urine $\mathrm{N}$ was relatively high in autumn (49\%) when urine was deposited on ryegrass 
receiving a fertilizer rate of $100 \mathrm{~kg} \mathrm{~N}$ ha- $1 \mathrm{yr}^{-}$ 1. Lower $\mathrm{N}$ fertilizer regimes can therefore lower the leaching potential of urine $\mathrm{N}$ in pastures. Khanal et al., (2010) carried out a field experiment in Nepal on farmer's field during 2009-2010, to test the efficacy of cattle urine alone and in combination with urea as a potential supplement to nitrogenous fertilizers in improving yield and quality of cauliflower cv. Kathmandu Local. The experiment was laid out in a randomized complete block design with eight treatments; $100 \mathrm{~kg} \mathrm{~N}^{-1}$ supplied by urea, $100 \mathrm{~kg} \mathrm{~N}^{-1}$ supplied by urine, $125 \mathrm{~kg} \mathrm{~N}^{-1}$ supplied by urine, $75 \mathrm{~kg}$ $\mathrm{N}$ ha $^{-1}$ supplied by urine, $50 \mathrm{~kg} \mathrm{~N} \mathrm{ha}{ }^{-1}$ supplied by urine, $100 \mathrm{~kg} \mathrm{~N} \mathrm{ha}^{-1}$ supplied by urea $\left(75 \mathrm{~kg}\right.$ ) and urine $(25 \mathrm{~kg}), 100 \mathrm{~kg} \mathrm{~N} \mathrm{ha}^{-1}$ supplied by urea $(50 \mathrm{~kg})$ and urine $(50 \mathrm{~kg})$, $100 \mathrm{~kg} \mathrm{~N} \mathrm{ha}{ }^{-1}$ supplied by urea $(25 \mathrm{~kg})$ and urine $(75 \mathrm{~kg})$ having three replications. Application of $125 \mathrm{~kg} \mathrm{~N}^{-1}$ through urine significantly increased vegetative characters. Application of $100 \mathrm{~kg} \mathrm{~N} \mathrm{ha}^{-1}$ through urine significantly increased yield and quality characters as compared to application of either higher or lower dose of urine. Fifty percent substitution of urea by urine produced better morphological, yield and quality character than other combinations of urine and urea. Singh et al., (2014) conducted a field experiment to assess the effect of varied levels of nitrogen and cow urine on rice crop during kharif season of 2009 with the six treatment combinations as T1 = NPK (120, $\left.60,60 \mathrm{~kg} \mathrm{ha}^{-1}\right), \mathrm{T} 2=\operatorname{NPK}\left(120,60,60 \mathrm{~kg} \mathrm{ha}^{-}\right.$ ${ }^{1}+$ cow urine $)$, T3 $=$ NPK $\left(100,60,60 \mathrm{~kg} \mathrm{ha}^{-1}\right.$ + cow urine),T4 = NPK $\left(90,60,60 \mathrm{~kg} \mathrm{ha}^{-1}+\right.$ cow urine $)$ and T5 $=$ NPK $\left(60,60,60 \mathrm{~kg} \mathrm{ha}^{-1}\right.$ cow urine) including control (T0). The application of nitrogen @ $90 \mathrm{~kg} \mathrm{ha}^{-1}$ with 60 $\mathrm{kg} \mathrm{ha}^{-1}$ potassium and phosphorus + cow urine (T4) was found to be the best treatment regarding growth, yield and nitrogen content of paddy. Patil et al., (2008) reported that foliar spray of cow urine and water on green gram. In case of foliar spray of cow urine results the higher growth and yield contributing characters significantly. The grain $\left(11.35 \mathrm{q} \mathrm{ha}^{-1}\right)$ and straw yield $(13.80 \mathrm{q}$ $\mathrm{ha}^{-1}$ ) along with biological yield (25.15 $\mathrm{q} \mathrm{ha}^{-}$ $\left.{ }^{1}\right)$, protein per cent in grains $(19.67 \%)$.

Gupta and Yadav (2001) conducted field trial in kharif season for evaluating cow urine efficacy against stem borers and cost benefit in soybean production. There was reduction in percent stem tunneling at almost all levels of cow urine. The yield data indicates that cow urine at 25, 50 and $75 \%$ concentration recorded significantly higher yield than control. Highest cost benefit ratio (1: 18.9) was obtained from $75 \%$ cow urine. Khanal et al., (2010) carried out a field experiment in Nepal on farmer's field during 2009-2010, to test the efficacy of cattle urine alone and in combination with urea as a potential supplement to nitrogenous fertilizers in improving yield and quality of cauliflower cv. Kathmandu Local. The highest curd yield and the highest benefit cost ratio (5.84) were observed by application of $100 \mathrm{~kg} \mathrm{~N} \mathrm{ha}{ }^{-1}$ through urine. Patil et al., (2008) studied foliar spray of cow urine and water on green gram. In case of foliar spray of cow urine results the higher gross (Rs. 22504) and net returns (Rs. 12558) with B: C ratio (2.32) per hectare due to foliar application of cow urine.

\section{Effect of Vermiwash}

Vermiwash is very good liquid manure and affect significantly on the growth and productivity of crop during foliar spray, (Subasashri, 2003). Buckerfield et al., (1999) has reported that, it is coelomic fluid extraction contains several enzyme, plant growth hormones like cytokinins, gibberlines and vitamins along with mocro and macro nutrients. It increases the disease resistant power of crop, (Yadav et al., 2005). Tripathi and Bhardwaj (2004) have reported that nitrogen in the form of mucus, nitrogenous 
excretory substances growth stimulating hormones and enzyme are present in vermiwash. Mahto and Yadav (2005) investigated the effect of vermiproducts and found that combined uses of vermicompost + vermiwash $(5$ or $10 \%)$ gave better performance with lower pest infestation by $24.26 \%$ over control. Manuring with vermicompost or in combination with foliar spray of vermiwash (5 or 10\%) recorded higher number of pods plant ${ }^{-1}(12.7-15.8)$ as compared to that in untreated control (7.9 pods plant-1). Among the treatments, soil application of vermicompost $(25 \mathrm{q} \mathrm{ha}$ ${ }^{1}$ equivalence $)$ and DAP (100 kg ha 1 equivalence) + foliar spray of vermiwash $(10 \%)$ at 30 days after sowing gave the best performance by reducing the pest infestation to the extent of $24.26 \%$, positively influenced nodulation and plant growth, and significantly increased number of pods plant-1, number of seeds pod- 1 and fresh yield of green seeds plant-1 by approximately 50, 40 and $70 \%$ over control, respectively. Khairnar et al., (2012) observed that application of foliar spray of vermiwash (at $501 \mathrm{ha}^{-1}$ ) and water at 15,35 and 50 days of crop age; and the water spray was given to the remaining plots as per treatment. The foliar spray of vermiwash recorded higher number of branches (3.23) over water spray (2.96). The mean grain yield was significantly higher $\left(10.42 \mathrm{q} \mathrm{ha}^{-1}\right)$ with vermiwash compared to water spray $(9.68 \mathrm{q}$ $\mathrm{ha}^{-1}$ ). Nath and Singh (2009) observed that different comination of vermiwash of animal and kitchen wastes have better growth and productivity of crops. The vermiwash is less expensive than chemical fertilizers, easily producible, eco-friendly and one of the best organic manure for foliar spray on the different crops. Varghese and Prabha (2014) study suggests that, vermiwash revealed potential application in sustainable development in agriculture biotechnology with respect to its origin, cost effectiveness, availability, reproducibility, reliability as well as biopesticide and ecofriendly soil conditioner. Tiwari and Singh (2016) reported that foliar applications of combinations of vermiwash obtained from animal dung and MSW with bio-pesticides neem (Azadiracta indica) oil,aquous extract of leaf, bark and vermiwash alone caused significant growth, start early flowering, enhance productivity as well as significant reduction $(\mathrm{P}>0.05)$ in pest infestation of tomato crop. The highest growth of tomato $(50.09 \pm 1.29 \mathrm{~cm})$ and maximum significant early flowring were observed after foliar application of mixture of vermiwash with neem oil in ratio of $(2: 1)$ whereas, the maximum significant early flowering period obtained after treatment of vermiwash of buffalo dung and MSW ( 2:1 ratio ) with neem oil. Nath and Singh (2015) was concluded that different combinations of vermiwash (buffalo dung) + gram bran with neem oil and aqueous extract of garlic is effective for the control of pod borer infestation on gram plant. Simultaneously, it also increased the growth, early flowering and enhanced the productivity of gram up to three times over control. Manyuchi et al., (2013) reported that vermicompost and vermiwash bio-fertilizers were obtained from vermicomposting waste corn pulp blended with cow dung manure. The $\mathrm{pH}$ and electrical conductivity was higher in the vermicompost compared to the vermiwash. The nitrogen and potassium content were $57 \%$ and $79.6 \%$ higher in the vermicompost as compared to the vermiwash respectively. However, the phosphorous content was $84 \%$ higher in the vermiwash as compared to the vermicompost. The vermiwash was $89.1 \%$ and $97.6 \%$ richer in $\mathrm{Ca}$ and $\mathrm{Mg}$ as compared to the vermicompost. Furthermore, the vermiwash was $97.8 \%$ rich in sodium content compared to the vermicompost. Nath and Singh (2011) reported that the combination of vermiwash with neem based pesticides is better option for the growth and productivity of soybean crop. Combination of vermiwash obtained from 
buffalo dung + and vegetable wastes with neem oil is very effective combination for growth and productivity of Soybean. It can be also stated that the use of foliar spray of vermiwash obtained from vermicomposts of buffalo dung + agro / kitchen wastes have sufficient potency to increase the growth, flowering, productivity and reduced pest's infestation of crop. Allahyari et al., (2014) reported that use of biological inputs and organic materials to improve the quality of crops and increase production without extension of cultivated lands is a significant issue in hydroponics (soilless culture) culture. The factors included two cultivars of tomato (Synda \& Newton), and four nutrient solution (manure vermiwash, mixed vermiwash, manure compost tea, mixed compost tea), with soil bed as control. The results showed that the effect of nutrient solutions and interaction effect between variety and the nutrient solution (variety $\times$ solution) were significant for all traits except for root dry weight. The results of qualitative traits analysis of extracts showed that the effect of nutrient solutions for the elements of phosphorus and potassium was not significant but for the other elements there were significant difference at the $1 \%$ level of probability.

Ansari and Sukhraj (2010) study revealed that combination organic fertilizers, vermicompost and vermiwash combination [VW+VC] compared with control [CON] and chemical fertilizers $[\mathrm{CHM}]$, had great influence on plant growth parameters. The average yield of Okra during trial showed a significantly greater response in $\mathrm{VW}+\mathrm{VC}$ compared with the control by $64.27 \%$. The fruits have a greater percentage of fats and protein content in $\mathrm{VW}+\mathrm{VC}$ when compared with those grown with chemical fertilizers by $23.86 \%$ and $19.86 \%$, respectively. The combination treatment [VW+VC] also have a significant influence on the biochemical characteristics of the soil with marked improvement in soil micronutrients. The combination treatment [VW+VC] was found better suggesting qualitative improvement in the physical and chemical properties of the soil. Nath and Singh (2012) reported that use of vermiwash extracted from vermicomposts of different combination of animal agro and kitchen wastes, is one of the effective liquid biofertilizer for growth and productivity of crops. The present study assesses that it has caused significant effect on the growth and productivity of paddy (Oryza sativa), maize (Zea mays) and millet (Penisetum typhoides) crops. The $10 \mathrm{mg} \mathrm{m}^{-2}$ of vermiwash buffalo dung with straw shows significant growth $(89.2 \pm 2.7 \mathrm{~cm})$ and $30 \mathrm{mg} \mathrm{m}^{-2}$ concentration of similar combination shows highly significant growth in paddy crops $(102.6 \pm 2.3 \mathrm{~cm})$ after 75 days. The $10 \mathrm{mg} \mathrm{m}^{-2}$ concentration of combination horse dung with gram bran caused significant growth $(85.2 \pm 4.3 \mathrm{~cm})$ 50days while at the same time $30 \mathrm{mg} \mathrm{m}-2$ concentration of combination of straw with buffalo dung and horse dung caused highly significant growth in maize crops. The combinations of buffalo dung with gram bran and with straw; and combination of horse dung with gram bran and with straw have significant growth in millet crops. All the concentrations of different combinations of animal agro and kitchen wastes have significant early start in flowering and enhance the productivity of crops. Chattopadhyay (2015) observed that the nutrients and growth promoting substances present in the vermiwash showed its potentiality in seed germination and seedling vigour. However, the vermiwash produced by cold stress diluted at the ratio of 1:5, produced superior result followed by 1:5 ratio vermiwash produced naturally, i.e. without stress. The use and application of vermiwash could play a beneficial role in sustainable agriculture as it is environment friendly, cost effective, reliable and easily available 
Gopalakrishnan et al., (2015) conducted an experiment on washings of vermicompost (called biowash or vermiwash) prepared from foliage of Jatropha (Jatropha curcas), Annona (Annona squamosa) and Parthenium (Parthenium hysterophorus) and evaluated against fungal pathogens viz. Fusarium oxysporum f. sp. ciceri (FOC; causes wilt in chickpea), Sclerotium rolfsii (causes collar rot in chickpea) and Macrophomina phaseolina (causes charcoal rot in sorghum). Crude biowash of the botanicals were partitioned against ethyl acetate and the resultant organic and aqueous fractions were tested against the fungi. Rawgol et al., (2011) studied the integrating aspects of Vermiculture, Moriculture and Sericulture. The products of vermiculture, including the vermicompost, vermicompost extract, vermicompost brew and the extracted body fluid of earthworms, the vermiwash were found to significantly increase the growth parameters of the mulberry plant and enhance the nutritive level of the mulberry leaves. Such leaves fed to the silkworm larvae (Bombex mori L) showed a significant positive effect on larval growth in terms of larval and silk gland weights and cocoon characters including fresh wet cocoon weights, wet weights of deflossed cocoons, dry weight of deflossed cocoons, and shell ratio percent as compared with controls. The floss weights however showed a significant decrease in the cocoons of the treated larvae as compared with controls. Vermiwashsmeared mulberry leaves of plants grown on vermicompost sprayed with vermicompost brew showed the maximum effect on the various silkworm parameters.

Tharmaraj et al., (2011) reported the impacts of various vermiproduct such as vemicompost, vermiwash and mixture of vermicompost and vermiwash on soil physico-chemical properties during the pot culture studies of samba rice. The soil treated with vermicompost had significantly more electrical conductivity in comparison to unamended pots. The addition of vermicompost in soil resulted in decrease of soil $\mathrm{pH}$. The physical properties such as water holding capacity, moisture content and porosity in soil amended with vermicompost were improved. The vermiproduct treated plants exhibit faster and higher growth rate and productivity than the control plants. Among the treated group, the growth rate was high in the mixture of vermicompost and vermiwash treated plants, than the vermicompost and vermiwash un-treated plants. The maximum range of some plant parameter's like number of leaves, leaf length, height of the plants and root length of plant, were recorded in the mixture of vermicompost and vermiwash. Mishra et al., (2014) concluded that the vermiwash with bio-pesticide is the better option for the growth, productivity as well as management of Lucinodes orbanalis infestation on brinjal crop. The foliar spray of vermiwash provide necessary nutrients to the growing plant for elongation, early flowering and fruiting phase. The bio-pesticide are more effective against larvae and caterpillar of fruit and shoot borer without contamination of fruits, so it is the best alternative of chemical fertilizers and pesticides for management of Lucinodes orbanalis population and enhancement of the productivity of fruit yield. Mishra et al., (2015) concluded that the vermiwash with bio-pesticide is the better option of the chemical fertilizer and pesticides for the management of Leptocoryza varicornis as well as productivity of rice crop. Since vermiwash is mild biopesticides and plant allelochemicals in their combination shows synergistic effect reduce the Leptocoryza varicornis population which ultimately enhances the productivity. Chauhan and Singh (2015) reported that effect of vermiwash with neem plant parts on the germination, growth, productivity of okra and its pest infestation. The significance 
germination of okra seed in vermiwash with aqueous extract of neem bark $(\mathrm{VW}+\mathrm{NB})$ $97 \pm 5.21 \%$ than other combinations and early germination was observed (11.48 \pm 0.49 days). The maximum height of okra $42.42 \pm 0.79 \mathrm{~cm}$ was observed in after 90 days by sprays of $\mathrm{VW}+\mathrm{NB}$. The combination of $\mathrm{VW}+\mathrm{NF}$ was important for high productivity of okra. The maximum productivity of okra plant was observed $773.23 \pm 20.64 \mathrm{~g} \mathrm{~m}^{-2}$ in treated with VW+NF. Tiwari and Singh (2015) reported that the foliar application of aqueous mixture of combination of vemiwash with neem oil, leaf and bark have increased the brinjal plant growth, early flowering, increased productivity. The binary combination of vermiwash with neem oil, leaf and bark results significant growth of brinjal plant. The highest growth of brinjal was $(30.01 \pm 0.86$ $\mathrm{cm}$ ) observed after spray of vermiwash of buffalo dung and municipal solid wastes (MSW) with neem oil in comparison to all other treatments.

Nath and Singh (2016) reported that the effect of vermiwash of different vermicomposts of animal agro and kitchen wastes observed on the growth, flowering periods and productivity of different Rabi crops viz. wheat, gram, pea and mustered. In case of wheat after 30 days of sowing the vermiwash of combination of goat dung with wheat and goat dung with vegetable wastes shows higher $26.20 \pm 0.97$ and $26.45 \pm 0.53 \mathrm{~cm}$ growth respectively, where as the maximum growth $65.00 \pm 0.88$ observed in conc. of $30 \mathrm{mg} \mathrm{m}^{-2}$ of combination of buffalo dung with rice bran. The significant productivity observed in combination of buffalo dung with rice bran i.e. $0.496 \pm 0.01 \mathrm{~kg} \mathrm{~m}^{-2}$ which is followed by the treatment of $10 \mathrm{mg} \mathrm{m}^{-2}$ concentration buffalo dung with rice bran. The highest significant productivity recorded in goat dung with wheat bran i.e. $0.621 \pm 0.06 \mathrm{~kg} \mathrm{~m}^{-2}$ conc. in $30 \mathrm{mg} \mathrm{m}^{-2}$. Kumar et al., (2013) observed that the application of vermiwash enhanced plant height and number of leaves $(56.29 \mathrm{~cm}$ and 6.14 days at 45 days after bud emergence), spike length and rachis (90.68 $\mathrm{cm}$ and $47.07 \mathrm{~cm})$, number of florets (15.08), vase-life (10.02 day) number of corms $\mathrm{m}-2$ (28.66), weight of corms $(50.68 \mathrm{~g})$ and number of cormels plant-1 (56.66). Same treatment was also effective to reduce number of days taken to spike emergence (81.73 day). Kumar et al., (2012) reported the application of vermiwash increases growth, flowering and corm yield characters of gladiolus when they are applied along with recommended fertilizers doses. Weerasinghe et al., (2006) have suggested that vermiwash is a natural growth supplements for tea, coconut and horticultural crops. Sobha et al., (2003) observed a significant growth and productivity in the black gram. Edwards et al., (2004) have been suggested that vermiwash influence the fruit quality. This study also concluded that vermiwash and vermicompost could be utilized effectively for sustainable plant production at low inputbasis green farming. Esakkiammal et al., (2015) reported that vermiwash acts as pesticide, disease curative and crop tonic and increase the yield of crops in multiples. Vermiwash and vermicompost were used to study their effect on the growth and yield of lab lab beans. The combination of vermicompost and vermiwash showed maximum positive effects on the growth and yield of lablab beans. The experimental results showed significant variations in plant growth and yield parameters. Anari and Sukhraj (2010) reported that vermiwash at a higher dilution is able to bring about increased germination rate and enhanced seedling growth in plants studied. The degree of response of the plants has varied and this could be attributed to the physiology of the plants under consideration and the concentration of vermiwash needs to be standardized to suit the plant to which it is applied. Fathima and Sekar (2014) reported 
that vermiwash can be used as a potent biofertiliser to improve the germination and seedling survival rates in crop plants growing on nutrition depleted soils thus paving the way for sutainable agriculture using organic farming practices. Zambare et al., (2008) observed vermiwash revealed potential application in sustainable development in agriculture biotechnology with respect to its origin, cost effectiveness, easily availability, time saving, reproducibility, reliability and eco-friendliness.

\section{Effect of Neem Extract}

Salako et al., (2008) investigations showed that neem leaf and seed powder or extracts controlled weevils in stored maize and cowpea, enhanced germination percentage, and seedling vigour. Also, a significant increase $(\mathrm{P}<00.5)$ in grain yield from the treated cowpea plots was obtained $(409 \mathrm{~kg}$ ha ${ }^{1}$ ) while that of the control plots was $301 \mathrm{~kg}$ $\mathrm{ha}^{-1}$. It also reduced fungal attack and infection on stored seeds and crops on the field. Dela et al., (2014) reported that neem leaves extracts, reduced survival and reproductive potential of the green peach aphid Myzus persicae. There induced mortality of nymphs throughout ingestion. These extracts showed interesting aphicide properties to Myzus persicae with dose response relationships well correlated which were observed. Podder et al., (2013) observed that Neem, mahogany, biskatali, pithraj extract treated plots showed significant variation over untreated control in aspects of percent population reduction of Epilachna beetle, neem oil at $13 \%$ concentration was the most effective among them. Moyin-Jesu et al., (2012) conducted an experiment on the extracts (neem leaf, wood ash and modified neem leaf) which applied at 1200 litres per hectare each, NPK 15-15-15 at $300 \mathrm{~kg} \mathrm{ha}^{-1}$ and poultry was applied at $6 \mathrm{t} \mathrm{ha}^{-1}$. The results showed that there were significant increases
$(\mathrm{P}<0.05)$ in the growth, fruit yield of tomato and soil $\mathrm{N}, \mathrm{P}, \mathrm{K}, \mathrm{Ca}, \mathrm{Mg}, \mathrm{pH}$ and O.M under different treatments compared to the control. For growth parameters, modified neem leaf extract had the highest values of plant height, stem girth, leaf area and number of branches of tomato plants compared to the poultry manure, neem leaf and wood ash extract (sole application). Modified neem leaf extract increased the plant height, stem girth, number of branches and leaf area by $13.2 \%, 9.5 \%$, $17.3 \%$ and $30 \%$ respectively compared to neem leaf extract. When compared to NPK 15-15-15 fertilizer, modified neem leaf extract increased plant height, stem girth, number of branches and leaf area of tomato plants by $2 \%, 5.4 \%, 3.4 \%$ and $31 \%$.

Moyin-Jesu (2012) studied the effect of extracts (neem leaf, wood ash and modified neem leaf) which were applied at 1200 litres per hectare each NPK 15-15-15 at $300 \mathrm{~kg} \mathrm{ha}^{-1}$ and poultry was applied at $6 \mathrm{t} \mathrm{ha}^{-1}$. The results reavealed that there were significant increases $(\mathrm{P}<0.05)$ in the maize growth and yield parameters (leaf area, plant height stem girth) grain yield, cob weight and \% shelling percentage) as well as in watermelon (vine length, stem girth, number of branches, fruits weight, population and fruit diameter) under sole and intercrop compared to the control treatment. Moyin-Jesu (2013) reported that liquid extracts from neem leaf (NLE), wood ash [WAE] and their modified forms (modified neem leaf MNLE) as fertilizer sources for improving soil fertility, growth and yield of garden egg (Solanium melogena L.). Six treatments were tested, namely neem leaf extract, wood ash extract (WAE), modified neem leaf extract, poultry manure, N P K 15-15-15 fertilizer (NPK) and control (no fertilizer or extract). Results indicated significant increases $(\mathrm{P}<0.05)$ in plant height, leaf area, leaf population, number of branches, fruit weight, fruit length, fruit diameter, soil $\mathrm{N}, \mathrm{P}, \mathrm{K}, \mathrm{Ca}$, and $\mathrm{Mg}$, content, 
and soil acidity under different fertilizer extracts compared to the control treatment. NLE yielded increased plant height, leaf area and stem girth of garden egg by $19.8 \%$, $21.5 \%$ and $5 \%$ respectively compared to wood ash treatment [WAE]. As compared to NPK, NLE also yielded increased plant height and stem girth, while, NPK yielded increased leaf area and number of branches compared to NLE. Plant height and leaf area increased by $15 \%$ and $11 \%$ respectively under NLE treatment as compared to poultry manure. For the yield parameters, modified NLE yielded increased garden egg fruit weight, fruit length and fruit diameter by $37.5 \%, 41.55 \%$ and $31.3 \%$ respectively as compared to WAE, and fruit weight, length and diameter by $42 \%$, $24 \%$ and $12.5 \%$ respectively as compared to NPK.

Moyin-Jesu (2014) observed that mixed extract of neem leaf + wood ash treatment gave the highest values of plantain growth and yield parameters and also improved the soil nutrients (soil N, P, K, Ca, Mg and 0.M) compared to NPK 15-15-15 fertilizer, neem leaf and wood ash extracts (sole forms) respectively. It is recommended that for better performance of plantain bunch weight, finger weight, finger diameter and length, growth parameters and improvement of soil fertility status, application of mixed extract of neem leaf + wood ash at $833.3 \mathrm{~L}$ ha-1 is appropriate. Anam et al., (2006) concluded that efficacy of neem oil on the mortality, growth and feeding responses of epilachna beetle showed that all the larval instars were susceptible to this oil. The LC50 values were higher at 3rd instar and it was lowest on 1st instar. The LT50 values of oil increases proportionately with increasing larval age and with decreasing oil concentration. Singh and Chauhan (2015) observed the aqueous extract of neem plant parts showed significant germination of Okra (Abelmoschus esculentus) plant may be due to presence of different plant hormones and micro-macro nutrients. Javed et al., (2007) reported that neem formulations form was neem leaves and neem cakes (a by-product left after the extraction of oil from neem seed) and one of the neem-refined products was "'aza'. The protective and curative soil application of these formulations significantly reduced the number of egg masses and eggs per egg mass on tomato roots. Protective application of neem crude formulations (leaves and cake) did not reduce the invasion of juveniles whereas aza at $0.1 \%$ w/w did. Curative application of neem formulations significantly reduced the number of egg masses and eggs per egg mass as compared with the control. Wondafrash et al., (2012) conducted a study on effects of neem oil (Nimbecidine $0.03 \%$ Aza) and water extracts of neem seed and leaf on African bollworm, Helicoverpa armigera at three concentration levels $(2.5 \%, 5 \%$ and $10 \%)$ under laboratory condition. In square dip experiment, high mortalities were statistically recorded from larvae treated with all concentration levels of seed extract and the two lower concentration levels of leaf extracts as compared to mortalities from control larvae. In larval immersion experiment, high mortalities were obtained from larvae treated with high concentration levels of both seed and leaf extracts as compared to control larvae. Three days after treatment application, significantly low numbers of squares were damaged by the larvae treated with the three concentration levels of seed extracts as compared to the control. Significant feeding reductions on artificial diet were also observed from larvae treated with various concentration levels of Nimbecidine, seed and leaf extracts at 6 and 9 days after treatment application in larval immersion experiment.

Sharma and Khan (2008) studied the Schistocerca gregaria F, adults which were treated against different concentrations of Neem products viz. Azadirachta indica 
(Leaves), Azadirachta indica (Green neem seed coat ), Azadirachta indica (Yellow neem seed coat) and Azadirachta indica (Neem seed kernel). The concentrations used to dip the maize leaves, upon which the insect feeds, were $0.005 \%, 0.01 \%, 0.025 \%, 0.05 \%, 0.1 \%$, $0.25 \%, 0.5 \%$ and $1.0 \%(\mathrm{v} / \mathrm{v})$ respectively, and results showed that the Schistocerca gregaria F. adults indicated the highest mortality $73.00 \%$ at $1.0 \%$ concentration of Azadirachta indica (Neem seed kernel). The mortality decreases with decrease in the concentration of Neem products. Least mortality response in noted against Azadirachta indica (Yellow neem seed coat), which is zero. Lokanadhan et al., (2012) observed that neem seed cake performs the dual function of both fertilizer and pesticide, acts as a soil enricher, reduces the growth of soil pest and bacteria, provides macro nutrients essential for all plant growth, helps to increase the yield of plants in the long run, bio degradable and eco friendly and excellent soil conditioner.

\section{Effect of fish wash}

Emenyonu et al., (2010) was observed that vegetable crop producers are mostly uses waste water for cultivation vegetable due to the nutrient content of the wastewater and the inaccessibility of freshwater. Castro et al., (2005) conducted an experiment to evaluate the use of fish effluent and well water to irrigate cherry tomatoes, Lycopersicum esculentum, cultivated in different levels of organic fertilizer. Two types of water (fish effluent and well water) and 5 levels of organic fertilizers were tested. Plants irrigated with fish effluent tended to present higher values of dry matter for root and aboveground parts, as well as average fruit weight. Meso et al., (2013) reported that the application of chemical fertilizers in ponds and activities of fish increases nutrient concentration of pond water. Application of pond water to crops during fish grow-out is feasible, but filters capable of removing particulates will be required if it is to be delivered through a drip irrigation system. Nutrient enrichment of pond water during aquaculture production is insufficient to meet crop nutrient demand, and fertilizer recommendations for crops should not be altered when pond water is used as an irrigation source. Wood et al., (2010) was conducted a field experiment on a vertisol at Sagana, Kenya, to determine the suitability of polyculture (Tilapia aureus) and African catfish (Clarias gariepinus) fish-pond effluent for drip irrigation of french bean (Phaseolus vulgaris cv. Samantha). Treatments included nonirrigated, unfertilized (-I -F); nonirrigated, fertilized $(-\mathrm{I}+\mathrm{F})$; irrigated with canal water, unfertilized $(+\mathrm{I}-\mathrm{F})$; irrigated with canal water, fertilized $(+\mathrm{I}+\mathrm{F})$; irrigated with fish pond effluent, unfertilized $(+\mathrm{P}-\mathrm{F})$; and irrigated with equal parts canal and pond water, unfertilized $(+\mathrm{IP}-\mathrm{F})$. For treatments utilizing fish-pond effluent, water was transferred from nearby polyculture ponds that received $20 \mathrm{~kg}$ $\mathrm{N} \mathrm{ha}^{-1} \mathrm{wk}^{-1}$ and $8 \mathrm{~kg} \mathrm{P} \mathrm{ha}{ }^{-1} \mathrm{wk}^{-1}$ over a 17 week cycle. Pond water contained higher concentrations of $\mathrm{N}\left(6.03 \mathrm{mg} \mathrm{kg}^{-1}\right)$ and $\mathrm{P}$ (3.89 $\left.\mathrm{mg} \mathrm{kg}^{-1}\right)$ than canal water. French bean harvest began 46 days after planting and continued for 28 days.

Salam et al., (2014) reported that fish effluents can supplement for organic fertilizers of vegetables production without affecting fish production. The recirculatory aquaponics system proved that it is not only a successful method for food crops production, but also a beneficial system to reuse aquaculture wastewater and safeguard the water resources of the country. Ramalingam et al., (2014) studied the potential use of trash fish manures in agricultural fields. Nutrient and minerals were analyzed in trash fish samples. High amount of nitrogen (6\%), phosphorous (5\%) and potassium (4\%) were present in trash fish and used for plant growth study. Three commercial plants viz. 
Lycoperscon esculantum, Hibiscus esculenta and Solanum melongena were selected for analysis. The shoot length, root length, total length, number of leaves, leaf length, biomass of the plant and roots division were measured in every 15 days interval upto 45 days. After 45 days, the percentage of root length growth of L. esculantum, $H$. esculenta and $S$. melongena in experimental plants showed 84, 99 and $82 \%$ and the shoot length growth were $50,45 \& 66 \%$ higher than the control plants. The outcome of the result in the experimental plants showed fast growth than the control plants. Bouchard et al., (2007) observed that the fish water had the highest nitrate content. Both fish water and Miracle-Gro ${ }^{\text {TM }}$ had $\mathrm{pH}$ level at neutral $(7.0 \mathrm{pH})$, with rain water being more acidic (4.5 pH). Fish water produced the higher plant in terms of length with an average stem length of 16.64 centimeters and an average root length of 9.08 centimeters, giving a total average length of 25.72 centimeters. This was 2.7 centimeters longer then second longest water typed plant which was rain water. Balraj et al., (2014) noted that fermented fish waste is found to enrich the soil nutrients required for plant growth and favourably influence the conducting functions of xylem and phloem vessels. Thus fish waste could be used as a valuable organic liquid fertilizer for better yield from crops at lesser cost and also without the harmful effects of chemical fertilizers. Jain (2011) results showed that pond water does contain enough nutrients to sustain plant growth. Nutrient-rich effluent from fish tanks can be used to fertigate hydroponic systems which would otherwise be contaminants building up to toxic levels in the tanks. This finding has real world application as every person depends on agriculture for survival. However, the current agricultural practices, with fertilizers and pesticides, cause harm to our earth, flora, and fauna. Hydroponics and aquaponics provide us with an environmentally friendly way of farming that produces healthier, greater, and faster yields. Myint et al., (2009) concluded with their experiment thet foliar application of fish waste extract @ 40cc/ 20 liter of water on soyabean crop showed the higher plant height $(74.83 \mathrm{~cm})$, leaf length $(11.87)$, plant dry weight $\left(4740.83 \mathrm{~kg} \mathrm{ha}^{-1}\right)$ and Seed yield (3850.83 $\left.\mathrm{kg} \mathrm{ha}^{-1}\right)$ as compare to control.

\section{Strategy for promotion of organic formulations}

From those previously stated information, it may be reasonable that natural formulations bring monstrous possibility to move forward soil fertility, crop productivity and pest management

It may be conundrum to record that most of information on these preparations has been experienced by Indian farmers since old times but number of apprehensions are persisting for use of organic formulations which requires initiation of systematic research for further descriptions.

Similar assessment for natural formulations prepared through ingredients from similar origin and there scientific explanation for their nutrient status, microbial consortia and other associated scientific information can resolve many apprehensions.

Impact, role played in package of practices will help for their acceptance in promotion of organic farming.

These can be prepared with little support and skill up gradation trainings.

There is need for delineation of nutrient status (macro and micro nutrients), plant growth promoting factors, immunity enhancer ability etc., for their quick acceptance by the scientific and farming community. 
After proper filtration, organic formulations can be used through drip/sprinkler as fertigation.

Comparative evaluation of aforesaid bio enhancers for their nutritive value and impact will help for their preparation and use.

There is need to work out its contribution in organic production and frequency of their use in different crops.

In conclusions, starting with the over enumeration, it can be concluded that organic formulations could be a potent source to move forward soil fertility, crop productivity and quality and additionally control of pest and diseases. This could additionally make a possibility elective to fertigation which is becoming common in most of the crops. However, consideration ought to be made that natural formulations which would utilized within limited quantities can't meet those whole nutrient requirement of the crops. These simply catalyze quick decomposition of organic wastes in to humus, hence incorporation of enough bio mass preferably combination of monocot and legumes duly supplemented with animal wastes will be helpful in quality production of humus, which is prerequisite for improving soil fertility and crop productivity. Combined with manures and frequent use of organic formulations can address many challenges of agriculture and will be pave way for sustainable agriculture through organic resources.

\section{References}

Akhter, N., Begum, M. F., Alam, S. and Alam, M. S. 2006. Inhibitory effect of different plant extracts, cow dung and cow urine on conidial germination of Bipolaris sorokiniana. J. Bio-sci., 14: 87-92.

Allahyari, S., Honarmand, S. J., Khoramivafa, M. and Zolnorian, H. 2014. Effect of vermicompost extracts (compost tea and vermiwash) on the vegetative growth of tomato (Lycopersicon esculentum Mill) under hydroponic conditions. Int. J. Biosci., 4(11): 171-181.

Anam, M., Ahmad, M. and Haque, M.A. 2006. Efficacy of neem oil on the biology and food consumption of Epilachna beetle, Epilachna dodecastigma (Wied.). J. Agri. Rural Develop., 4(1): 83-88.

Andreeilee, B.F., Santoso, M., and Maghfoer, M.D. 2015. The effect of organic matter combination and azola dosage (Azolia pinnam) on growth and the production of paddy (Oryza sp.) Ciherang variety. Res. J. Agron., 9(1-6): 1-4.

Ansari, A.A. and Sukhraj, K. 2010. Effect of vermiwash and vermicompost on soil parameters and productivity of okra (Abelmoschus esculentus) in Guyana. African J. Agri. Res., 5(14): 1794-1798.

Baghele, R.D., Dhaduk, B.K., Chawla, S.L. and Jadeja, R. 2014. Effect of growth regulators and cow urine on rose (Rosa hybrida) cv. poison. BIOINFOLET-A Quarterly J. Life Sci., 11(2c): 673-676.

Balraj, T.H., Palani, S. and Arumugam, G. 2014. Influence of Gunapaselam, a liquid fermented fish waste on the growth characteristics of Solanum melongena. $J$. Chem. Pharma. Res., 6(12): 58-66.

Bouchard, N., Harmon, K., Markham, H., Vandefifer, S., Thomas, S., \& Morrison, E. 2007. Effect of Various Types of Water on The Growth of Radishes (Raphanus sativus)

Buckerfield, J.C., Flavel, T., Lee, K.E. and Webster, K.A. 1999. Vermicompost soil and liquid form as plant growth promoter. Pedobiologia, 42:753-759.

Castro, R.S., da Silveira Borges Azevedo, M., \& Barbosa, M.R. 2005. Effect of using fish effluent and well water to irrigate cherry tomato cultured in different levels of organic manure. Revista Ciência Agronômica, 36(3): 396.

Chauhan, H.K. and Singh, K. 2015. Potancy of vermiwash with neem plant parts on the infestation of eCariasvittella (fabricius) and productivity of okra (Abelmoschus esculentus)(L.) Moench. Asian J. Res. Pharmaceutical Sci., 5(1): 36-40. 
Déla, M.A., Koffivi, K.G., Komina, A., Arnaud, A., Philippe, G. and Adolé, G.I. 2014. Evaluation of neem leaves-based preparations as insecticidal agents against the green peach aphid, Myzus persicae (Sternorrhyncha: Aphididae. African $J$. Agri. Res., 9(17): 1344-1352.

Devakumar, N., Subha, S., Rao, G.G.E. and Imran Khan, J. 2014. Studies on soil fertility, cow urine and panchagavya levels on growth and yield of maize. Building Organic Bridges, 2: 627-630.

Edwards, C.A., Domínguez, J. and Arancon, N.Q. 2004. The influence of vermicomposts on plant growth and pest incidence. In, S.H Shakir and W.Z.A. Mikhail, (Eds. Soil Zoology for Sustainable Development in the 21 st century. pp (397-420): Cairo.

Emenyonu, C.A., \& Ada, H.U. 2010. Effects Of Waste Water Use On Vegetable Crop Production In Imo State, Nigeria. Researcher, 2(10).

Esakkiammal, B., Lakshmibai, L. and Sornalatha, S. 2015. Studies on the combined effect of vermicompost and vermiwash prepared from organic wastes by earthworms on the growth and yield parameters of dolichous lab lab. Asian J. Pharmaceutical Sci. Technol., 5(4): 246-252.

Fathima, M. and Sekar, M. 2014. Studies on growth promoting effects of vermiwash on the germination of vegetable crops. Int. J. Curr. Microbiol. App. Sci., 3(6): 564-570.

Gahukar, R.T. 2013. Cow urine: a potential biopesticide. Indian J. Entomol., 75(3): 212-216.

Geetanjaly and Tiwari, R. 2014. Antifeedant and growth regulatory effects of neem Leaf extracts against Spilarctia obliqua (walker). The bioscan, 9(3): 1151-1156.

Gopalakrishnan, S., Kannan, I.G.K., Alekhya, G., Humayun, P., Meesala, S.V. and Kanala, D. 2015. Efficacy of jatropha, annona and parthenium biowash on Sclerotium rolfsii, Fusarium oxysporum f. sp. ciceri and Macrophomina phaseolina, pathogens of chickpea and sorghum. African $J$. Biotechnol., 9(47): 8048-8057.

Gupta, M.P. 2005. Efficacy of neem in combination with cow urine against mustard aphid and its effect on coccinellid predators. Natural Product Radiance, 4: 102-106.

Jain, S. 2011. Hydroponics vs. aquaponics: can fish waste provide enough nutrients to sustain plant growth. California state science fair, J1915.

Javed, N., Gowen, S. R., Inam-ul-Haq, M. and Anwar, S. A. 2007. Protective and curative effect of neem (Azadirachta indica) formulations on the development of rootknot nematode Meloidogyne javanica in roots of tomato plants. Crop protection, 26(4): 530-534.

Kekuda, P. T., Vivek, M. N., Manasa, M., Kambar, Y., Nawaz, N. A. and Raghavendra, H. L. 2014. Antifungal effect of cow urine extracts of selected plants against Colletotrichum capsici isolated from anthracnose of chilli. Int. J. Agri. Crop Sci., 7(3): 142.

Khairnar, A. V. and Gunjal, B. S. 2012. Effect of potash fertilization and foliar spray of vermiwash on growth and yield of green gram (Vigna radiata L). Int. J. Agri. Sci., 8(1): 307-308.

Khanal, A. Shakya S. M., Shah, S. C. and Sharma, M. D. 2010. Utilization of urine waste to produce quality cauliflower. The J. Agri. Environ., 12: 84-90.

Kumar, P., Shekhar, C., Basoli, M. and Kumar, V. 2012. Sequential spray of vermiwash at critical stages influences growth and quality in gladiolus cv. white prosperity. Progressive Agri., 12(1): 103-109.

Kumar, P., Shekhar, C., Basoli, M. and Kumar, V. 2013. Sequential spray of vermiwash at critical stages influences growth and quality in gladiolus cv. white prosperity. Annals of Hort., 6(1): 71-75.

Ledgard, S.F., Sheath, G. W., \& Gillingham, A. G. 1982. Influence of some soil and pasture components on the growth of hill country pastures 1. Winter and spring production. New Zealand J. Experimental Agri., 10(3): 239-244.

Leterme, P., Barre, C., and Vertes, F. 2003. The fate of $15 \mathrm{~N}$ from dairy cow urine under pasture receiving different rates of $\mathrm{N}$ fertilizer. Agronomie, 23: 609-616.

Lithourgidis, A.S., Matsi, T., Barbayiannis, N. and Dordas, C.A. 2007. Effect of liquid 
cattle manure on corn yield, composition and soil properties. Agronomy J., 99(4): 592-596.

Lokanadhan, S., Muthukrishnan, P. and Jeyaraman, S. 2012. Neem products and their agricultural applications. $J$. Biopesticides, 5: 72-76.

Mahto, T. P. and Yadav, R. P. 2005. Effect of vermicompost alone and in combination with chemical fertilizer on stem fly incidence and yield attributes in vegetable peas under Bihar conditions. J. Appl. Zool. Res., 16(1): 70-72.

Manyuchi, M. M., Phiri, A., Muredzi, P. and Chitambwe, T. 2013. Comparison of vermicompost and vermiwash biofertilizers from vermicomposting waste corn pulp. In Proceedings of World Academy of Science, Engineering and Technology (No. 78, p. 346. World Acad. Sci. Engi. Technol. (WASET).

McNaught, K. J. and Chrisstoffels, P. J. 1961. Effect of sulphur deficiency on sulphur and nitrogen levels in pastures and lucerne. New Zealand J. Agri. Res., 4(1-2): 177-196.

Meso, M. B., Wesley Wood, C., Karanja, N. K., Veverica, K. L., Woomer, P. L., \& Kinyali, S. M. 2004. Effect of fish pond effluents irrigation on French beans in central Kenya. Communications in Soil Sci. Plant Analysis, 35(7-8): 1021-1031.

Minocheherhomji, F. P. and Vyas, B. M. 2014. Study of the antimicrobial activity of cow urine and medicinal plant extracts on pathogenic human microbial strains. Int. J. Adv. Pharm. Biol. Chem., 3: 836-840.

Mishra, K., Singh, K. and Tripathi, C.P.M. 2015. Organic farming of rice crop and management of infestation of Leptocoryza varicornis through combined effect of vermiwash with biopesticides. Res. J. Sci. Technol., 7(4): 205-211.

Mishra, K., Singh, K. and Tripathi, C.P.M. 2014. Journal homepage: http://www. Journal.ijar. com, Int. J. Adv. Res., 2(1): 780-789.

Moyin-Jesu, E.I. 2012. Comparative evaluation of modified neem leaf, neem leaf and woodash extracts on soil fertility improvement, growth and yields of maize (Zea mays L) and watermelon (Citrullus lanatus)(Sole and Intercrop). Agri. Sci., 3(1): 90.
Moyin-Jesu, E.I. 2013. Comparative evaluation of neem leaf (azardiracta indica 1): wood ash and modified neem leaf extracts on the soil fertility, growth and yield of garden eggplant (Solanium melongena) J. Agri. Sci. Technol., 1(3): 84-92.

Moyin-Jesu, E.I. 2014. Effects of water extracts of neem (Azadirachta indica L.) leaf, wood ash and their mixture on soil chemical composition and growth and yield of plantain (Musa sapientum L). American J. Experimental Agri., 4(7): 836.

Moyin-Jesu, E.I., Micah, O. and Akinola, M.O. 2012. Comparative evaluation of modified neem leaf and wood Ash extracts on soil fertility status growth and fruit yields of tomato (Lycopersicon esulentum L): G.J.B.B., 1(2): 271-276.

Mudhita, I.K., Umami, N., Budhi, S.P.S., Baliarti, E., Noviandi, C. T., Kustono, I. and Wattimena, J. 2016. Effect of bali cattle urine on legume cover crop puero (Pueraria javanica) productivity on an east borneo oil palm plantation. Pak. J. Nutrition, 15(5): 406-411.

Myint, T. Z., Sooksathan, I., Kaveeta, R., \& Juntakool, S. 2009. Effects of different organic amendments an $d$ chemical fertilizer on plant growth and grain yield of soybean on pakchong soil series. Kasetsart J. Natural Sci., 43: 432-441.

Nath, G. and Singh, K. 2012. Effect of vermiwash of different vermicomposts on the kharif crops. J. Central European Agri., 13(2): 379-402.

Nath, G. and Singh, K. 2011. Effect of foliar spray of bio pesticides and vermiwash of animal, agro and kitchen wastes on soybean (Glycime max L.) crop. Botany Res. Int., 4(3): 52-57.

Nath, G. and Singh, K. 2015. Combined effect of vermiwash with biopesticides against infestation of pod borer (Helicoverpa armigera hub). Int. J. Zool. Investigations, 1(1): 40-51.

Nath, G. and Singh, K. 2016. Vermiwash: a potent liquid biofertilizer. Res. J. Sci. Technol., 8(1): 21-30.

Pathak, R.K. and Ram, R.A. 2013. Bio-enhancers: A potential tool to improve soil fertility, plant health in organic production of 
horticultural crops. Progressive Horticulture, 45(2): 237-254.

Patil, S. M., Khairnar, A. V., Patil, H. M. and Gaikwad, C. B. 2008. Response of potash and foliar spray of cow urine on growth and yield of summer greengram (Vigna radiata L). Int. J. Agri. Sci., 4(2): 446-449.

Patil, S. V., Halikatti, S. I., Hiremath, S. M., Babalad, H. B., Sreenivasa, M. N., Hebsur, N. S. and Somanagouda, G. 2012. Effect of organics on growth and yield of chickpea (Cicer arietinum L.) in vertisols. Karnataka J. Agri. Sci., 25(3).

Podder, S., Uddin, M. M. and Adnan, S. M. 2013. Assessment of the effectiveness of different botanicals and chemical insecticide in managing Epilachna beetle, Epilachna dodecastigma (Wied.) Int. Res. J. Agri. Sci., 1(4): 52-59.

Qibtiyah, M., Aini, N. and Soelistyono, R. 2015. The effect of application time and dosage of biourine on growth and production of rice (Oryza Sativa L.) 8(1) 26-30.

Rakesh, K. N., Dileep, N., Junaid, S., Prashith, K. T. R., Vinayaka, K. S. and Noor, N. A. S. 2013. Inhibitory effect of cow urine extracts of selected plants against pathogens causing rhizome rot of ginger. Sci. Technol. Arts Res. J., 2(2): 92-96.

Ramachandrudu, K. and Thangam, M. 2007. Response of plant growth regulators, coconut water and cow urine on vegetative growth, flowering and corm production in gladiolus. J. Ornamental Horticulture, 10(1): 38-41.

Ramalingam, V., Thirunavukkarasu, N., Chandy, N., \& Rajaram, R. 2014. Proximate composition of trash fishes and their utilization as organic amendment for plant growth. J. the Marine Biol. Assoc. India, 56(2): 12.

Rawgol, Y.K., Priyadarshini, P.M., Sharma, V. and Radha, D.K. 2011. Efficacy of vermiwash-smeared mulberry leaves on cocoon characters of multivoltine hybrid mulberry silkworm Bombyx Mori L: Kolar Gold (K.G.) race. Int. J. Res. Sci. Technol., 1(2).

Salako, E. A., Anjorin, S. T., Garba, C. D. and Omolohunnu, E. B. 2008. A review of neem biopesticide utilization and challenges in Central Northern Nigeria. African J. Biotechnol., 7(25).

Salam, M. A., Hashem, S., Asadujjaman, M., \& Li, F. 2014. Nutrient Recovery from in Fish Farming Wastewater: An Aquaponics System for Plant and Fish Integration. World J. Fish Mar. Sci., 6: 355-360.

Sharma, T. and Khan, A.M. 2008. Toxic effect of neem (Azadirachta indica) extracts against Schistocerca gregaria f. adults under laboratory conditions. J. Environ. Res. Develop., 2(4).

Singh, M.K., Singh, R.P. and Rai, S. 2014. Effect of nitrogen levels and cow urine on soil $n$ status, growth and yield on paddy (Oryza sativa L.): 16(1): 54-57.

Singh, R., Babu, S., Avasthe, R. K., Yadav, G. S., Chettri, T. K., Phempunadi, C. D. and Chatterjee, T. 2015. Bacterial inoculation effect on soil biological properties, growth, grain yield, total phenolic and flavonoids contents of common buckwheat (Fagopyrum esculentum Moench) under hilly ecosystems of North-East India. African J. Microbiol. Res., 9(15): 11101117.

Sobha, R., Ganesh, P., Mohan, Y.P., Saleem, S.S. and Laxmi, G.S.V. 2003. Effect of vermiwash on the growth of black gram (Vigna mungo). J. Eco. Biol., 30(1): 77- 79.

Sobhana, A. 2014. Effect of bioregulators and cow's urine on flower production in jasmine (Jasminum sambac. Asian J. Horticulture, 9(1): 160-163.

Subasashri, M. 2003. Vermiwash collection and its pesticidal properties. The Hindu, 17: 1-2.

Tharmaraj, K., Ganesh, P., Kolanjinathan, K., Suresh Kumar, R. and Anandan, A. 2011. Influence of vermicompost and vermiwash on physico chemical properties of rice cultivated soil. Curr. Bot., 2(3): 18-21.

Tiwari, K. S. and Singh K. 2016. Combined effect of liquid biofertilizer with biopesticide on yield of tomato (solanum lycopersicum 1.) and infestation of Helicoverpa armigera (hubner). J. Bio. Innov., 5(1): 144-163.

Tiwari, S.K. and Singh, K. 2015. Potency of combination of liquid biofertilizer with biopesticide on productivity of brinjal and infestation of Leucinodes orbonalis (Pyraustidae: Lepidoptera). Int. J. Pure 
App. Biosci., 3(5): 62-72.

Tripathi, G. and Bharadwaj, P. 2004. Comparative studies on biomass production, life cycles and composting effiency of Eisenia foetida (Savigny) and Lampito mauritii (Kingberg. Biores. Technol., 92: 275-278.

Varghese, S.M. and Prabha, M.L. 2014. Biochemical characterization of vermiwash and its effect on growth of capsicum frutescens. Malaya J. Biosci., 1(2): 86-91.

Weersinghe, K.L.K., Mohotti, K.M., Herath, C.N., Sanarajeewa, A., Liyangunawardena, V. and Hitinayake, HMGSB. 2006. Biological and chemical properties of vermiwash a natural plant growth supliment for tea, coconut and horticulture crops 12 September Forestry and Environment Symposium, University of Jayewardenepura, Sri Lanka.

Wondafrash, M., Getu, E. and Terefe, G. 2012.
Survival and feeding of african bollworm, Helicoverpa armigera (Hubner) (Lepidoptera: Noctuidae) affected by neem, Azadirachta indica(A. Juss) Extracts. World J. Agri. Sci., 8(3): 280-285.

Wood, W.C., Meso, B.M., Veverica, L.K., \& Karanja, N. 2001. Use of pond effluent for irrigationinan integrated crop/aquaculture system. Eighteenth Annual Technical Report. Pond Dynamics/Aquaculture CRSP, Oregon State University, Corvallis, Oregon, 69-78.

Yadav, A.K., Kumar, K., Singh, S. and Sharma, M. 2005. Vermiwash- A liquid biofertilizer, Uttar Pradesh J. Zool., 25(1): 97-99.

Zambare, V.P., Padul, M.V., Yadav, A.A. and Shete, T.B. 2008. Vermiwash: biochemical and microbiological approach as ecofriendly soil conditioner. Aron J. Agric. Biol. Sci., 3: 1-5.

\section{How to cite this article:}

Sudhanshu Verma, Abhishek Singh, Swati Swayamprabha Pradhan, R.K. Singh and Singh, J.P. 2017. Bio-efficacy of Organic Formulations on Crop Production-A Review. Int.J.Curr.Microbiol.App.Sci. 6(5): 648-665. doi: https://doi.org/10.20546/ijcmas.2017.605.075 